\title{
28 Resarach Square \\ Influence of vegetation cover change on the decadal trend of summer seasonal air temperature in the Pannonian Basin
}

\author{
Albert Ruman ( $\sim$ albert.ruman@hidmet.gov.rs ) \\ Republic Hydrometeorological Service of Serbia https://orcid.org/0000-0003-2738-6233 \\ Anna Ruman \\ Republic Hydrometeorological Service of Serbia
}

\section{Research Article}

Keywords: vegetation, MPI-ESM, temperature, trend, albedo

Posted Date: March 12th, 2021

DOI: https://doi.org/10.21203/rs.3.rs-203476/v1

License: (c) (i) This work is licensed under a Creative Commons Attribution 4.0 International License. Read Full License 


\section{Abstract}

The influence of land surface vegetation on the atmosphere processes in the planetary boundary layer is of great importance for the study of weather and climatic conditions in the Earth's climate system. Vegetation, as an integral part of the Earth's climate system, has a great influence on the exchange of energy between land and the atmosphere and, consequently, a significant role in defining weather and climate patterns at the global, regional and local scales. However, due to the constant anthropogenic impact, this vegetation system is continuously changing mostly due to deforestation, afforestation, and forest fires which make it difficult to present them during the research of the Earth's climate system. The aim of this study is to examine the impact of the regional vegetation change on the seasonal surface air temperature and was performed using the Max-Planck-Institute Earth System Model. The region of our research is located in the Pannonian Basin and is one of many regions in which the anthropogenic impact on geophysical changes in the environment is considerable. The study was carried out over a ten-year period, from 2002 to 2011 , during which we showed that the change in the presence percentage between certain types of vegetation leads to warming up as well as cooling down of air during the summer season. We have also shown to what extent this change in vegetation has an impact on the surface air temperature trend as well as on the change in the albedo and flux of sensible heat.

\section{Introduction}

Vegetation affects the Earth's climate through various processes that can be divided into two basic groups such as the bio-geophysical and biogeochemical. The main bio-geophysical processes include surface energy, moisture, and momentum fluxes which are defined by the physical properties of the vegetation such as albedo, aerodynamic roughness, and leaf area (Claussen et al., 2001; Betts, 2006; Bonan, 2008; Port et al., 2012). While the main chemical processes include the interaction with carbon dioxide $\mathrm{CO}_{2}$ and ozone $\mathrm{O}_{3}$ as well as aerosol production due to the release of hydrocarbons (Arneth et al., 2010). Each of these processes significantly affects the exchange of energy between the land and the atmosphere, resulting in changes in the regional and global circulation of the atmosphere and, thus, the impact on climate. For example, forest vegetation has a small albedo, so it absorbs a large part of the incoming shortwave solar radiation. Most of this radiation, through long-wave radiation, is spent on heating the air above forest vegetation through radiation, conduction, and convection (Betts and Ball, 1997). In the surface layers, the air is cooled by the process of evapotranspiration, while, due to the transfer of latent heat to higher layers of the atmosphere, it is heated during its release, i.e., we observe the production and transport of water vapor and its influence as a component gas of the greenhouse effect on the air heating and cooling. Aerodynamically, forest vegetation is a very rough surface that increases turbulence and reduces wind speed in the surface layer of the atmosphere (Rotenberg and Yakir, 2010; Vautard et al., 2010). This increase in turbulence above forest vegetation encourages convection and, consequently, the formation of clouds and the frequency of precipitation over areas covered with forest vegetation (Pielke et al., 2007; Wulfmeyer et al., 2011; Ellison et al., 2012). Also, an increase in cloudiness above the forest vegetation can leads to an increase in the albedo of cloudiness, which affects local and regional air cooling (Pongratz et al., 2009; Teuling et al., 2017).

The intensity and duration of these processes mostly depend on the type of forest vegetation, which we can represent through the geographical area in which it is present. Due to this division, we can define the following types of forest vegetation: northern, temperate, and tropical forests (Bonan, 2008). For example, northern forests due to the small albedo have a great influence on the regional air temperature throughout the year and relative to the other two types, they also have the greatest influence on the global mean temperature, while the $\mathrm{CO}_{2}$ absorption and evapotranspiration are lower (Betts, 2006; Bonan, 2008; Lee et al., 2011). The impact of temperate forests on the climate relative to the northern or tropical ones is more complex and uncertain, mainly due to its mixed composition and vegetation period of 
certain forest species (Bala et al., 2007; Bonan, 2008; Tölle et al., 2018). As a result, the influence between cooling and heating varies regionally and seasonally (Teuling et al., 2010). This type of forest is particularly interesting to us because it mitigates the effects of heatwaves over a long period of time in the areas of Central and Western Europe (Tueling et al. 2010; Stéfanon et al., 2012; Bastos et al., 2013; Bevan et al., 2013). It also covers the areas in the regions where the human population greatly influences environmental change by changing local surface conditions.

This is just a small overview of how important and complex the impact of forest vegetation on Earth's Climate System (ECS) is. However, due to the development of complex numerical climate models and weather forecasting models, we have a better insight into the research of the interaction of vegetation with the atmosphere by numerical simulations. With this method, various simulations were performed in which regional or global analyses of the influence of the areas under vegetation on climate and weather conditions were performed. In general, the results obtained by this method showed that there is an increase in surface air temperature and a decrease in precipitation in areas where forest vegetation was removed. For example, Schneck and Mosbrugger (2011) studied the local and regional impact of deforestation in Southeast Asia, where they found that in areas where forest vegetation was removed, the surface air temperature increased and the precipitation decreased, and the circulation in the ocean changed locally. Pitman et al. (2009) performed a series of numerical simulations with the decrease in the areas under forest vegetation and concluded that some numerical models resulted in a decrease in the surface temperature, whereas others increased. The changes they obtained for total precipitation were generally small while a certain number of models gave a decrease in precipitation over deforested areas. Sanchez et al. (2007) observed the potential impact of changes in the area under forest vegetation in Europe where they concluded that precipitation in most of Europe was higher where the area under forest vegetation increased and the surface air temperature decreased by 1 to 3 degrees Kelvin scale. Anav et al. (2010) examined the impact of a decrease and increase in the area under forest vegetation on the climate in Europe. They concluded that there is an increase in the number of warm days due to the decrease in the area under forest vegetation and a decrease in the number of warm days due to the increase in the area under forest vegetation.

Depending on the type of research, we use models for numerical weather prediction (NWP), regional climate models (RCM), or global climate models (GCM). These models should contain numerical parts in which the dynamic development of plant mass is defined, i.e., they should contain physical and chemical processes through which vegetation cycles are defined, as well as the processes of photosynthesis and evapotranspiration throughout the year. The role of such numerical parts is to simulate the physical and thermodynamic conditions that occur in the vegetation layer and the layer above it as accurately as possible and therefore they affect the accuracy of the result.

\section{Method And Data}

We presented the results in a time as well as space framework. The seasonal period was taken to be the time frame, while for the spatial frame, we presented the results at the local and regional scale (Fig. 1). When defining the seasonal period as a time frame, we used the meteorological definition for the seasonal value, which is based on the annual surface air temperature cycle. That is, meteorologists and climatologists divide the seasons into groups of three months using a standard civil calendar based on the annual surface air temperature cycle. Thus, meteorological spring includes March, April, and May (MAM); meteorological summer includes June, July, and August (JJA); meteorological autumn includes September, October, and November (SON) and meteorological winter includes December, January, and February (DJF). Mean seasonal air temperatures (MST) are calculated as the arithmetic mean between the mean monthly air temperatures that make up the same season. For our research, we defined the MST at the surface (MST $2 \mathrm{~m}$ ) as well as MST at 13 vertical levels (MST lev) of the atmosphere located near the Earth's surface, and we presented them with isobaric surfaces expressed in hecto Pascal (hPa). We defined the multiannual or decadal average of MST as the arithmetic mean between all ten-time steps that make up the summer mean seasonal values, that is, for JJA season.

Page $3 / 23$ 
The results for the areas at the local scale marked with $A 1, A 2, A 3, \ldots, A 11$, and $A 12$ (Fig. 1) are obtained as the arithmetic mean between 4 nearby model grid points marked with black circles. Depending on the geographical position, we have grouped these local areas into the southern area consisting of $A 1, A 2, A 3$, and A4 local areas, the central area A5, A6, A7, and $A 8$, and the northern area consisting of $A 9, A 10, A 11$, and $A 12$. For the area at the regional scale, we obtained the results as the arithmetic mean value between all model grid points that cover the spatial area of our research, and there are 20 in total, i.e., the region includes a resolution of $5 \times 4$ model points, 5 in the longitudinal and 4 in the meridional direction (Fig.1).

To examine the impact of the change in the percentage between certain types of vegetation in the Pannonian Basin on the local and regional climate, we will use the method of numerical simulation using GCM developed at the Max Planck Institute (MPI) for Meteorology in Hamburg and integrated into the Earth Sistem Modeling (MPI-ESM) model. To perform numerical simulations, we use MPI-ESM (Stevens et al., 2013), which consists of the following models: atmospheric general circulation model ECHAM6 (European Centre Hamburg 6th generation); land-surface model JSBACH (Jena Scheme for Biosphere-Atmosphere Coupling in Hamburg); and oceanic general circulation model MPIOM (Max Planck Institute Ocean Models). Their parallel connection during the operation was achieved by the OASIS3-MCT (Ocean Atmosphere Sea Ice Soil - Model Coupling Toolkit) model developed at CERFACS (Centre Europeen de Recherche et Formation Avancee en Calcul Scientifique). The OASIS3-MCT (Valcke, 2013) software enables us to synchronize the exchange of information between the numerical models, which represent different components of the Earth's climate system, i.e., it performs interpolation and communication between the grid points of the different models.

For our research, we determined the time from January 1, 2002, to December 31, 2011, that is, we did a decadal period of numerical simulations for a given period. The numerical simulation was performed three times, i.e., the whole research was divided into three steps. In the first step, we performed a numerical simulation for a given period with vegetation from 2002. In this step, we determined the control experiment through which we defined the deviation of the output results of the MPI-ESM from the approximately real state. In the second step, the vegetation cover from the period of 2002 was replaced with the vegetation cover from the pre-industrial revolution, i.e., from the year 850 , while in the third step, the vegetation cover from 2002 was replaced with the future vegetation cover from the 2050 year. Changes with the vegetation cover is done only in the area marked in Figure 1, while outside that area the vegetation cover is the same for all three steps in the experiment. Later in the text, we will mark these three numerical simulations with $\mathrm{CF}_{2002}(\mathrm{Cover}$ Fraction from the year 2002) as the first step, $\mathrm{CF}_{850}$ (Cover Fraction from the year 850) as the second step, and $\mathrm{CF}_{2050}$ (Cover Fraction from the year 2050) as the third step in our research.

To simulate the initial physical and thermodynamic conditions that occur in the global ECS as accurately as possible, we used four-dimensional data assimilation based on the method of Newton's relaxation or known as the "nudging" method (Krishnamurti et al. 1991; Jeuken et al. 1996). Newton's relaxation method is a method that reduces the deviations of simulated trajectories from the trajectories obtained by observation or from simulated analyses in a given time and the entire space. These projections of trajectories can represent certain values of the state of the atmosphere, such as temperature, vorticity, divergence, and the logarithm of the surface pressure (Giorgeta et al., 2013a). The solution of Newton's relaxation equation in the ECHAM6 model is presented implicitly and explicitly. For our research, we used an implicit solution with standard periods of relaxation time (Lohmann and Hoosel, 2009; Rast et al., 2013). In all three steps of the experiment, the assimilation will be continuously forced for four months during the duration of numerical integrations, i.e., from January 1, 2002, to April 31, 2002. During this period, we performed numerical simulations with the inclusion of nudging assimilation of atmospheric data such as surface pressure logarithm, divergence, vorticity, and air temperature which we have taken over by the European Centre for Medium-Range Weather Forecasts (ECMWF ERA-Interim) (Berrisford et al., 2011). 
The advantage of the research done with the method of numerical simulations using the MPI-ESM model is that this model covers most of the ECS, i.e., we can say that it covers all relevant processes that define the global circulation in the atmosphere and oceans. For the needs of the research, we prepared the models in the following way.

\subsection{Model setup}

The resolution of the MPIOM model is given with 256 grid points in the zonal and 220 grid points in the meridional direction (Wetzel et al., 2011), where the North Pole is located in Greenland and the South Pole in Antarctica, and this grid of points is often called bipolar. The horizontal points of the grid are arranged in the Arakawa C-grid (Arakawa and Lamb, 1977). The vertical resolution is represented by 40 levels in the z-coordinate system, while the time step of the model is $\Delta \mathrm{t}_{\text {ocean }}=2700 \mathrm{~s}$. The initial conditions required for the MPIOM model were taken over from the Copernicus Marine Service (CMS).

The ECHAM6 model is set to horizontal resolution with 192 grid points in the zonal direction while in the meridional direction, there are 96 grid points. Vertical resolution is represented by 47 levels over the $\sigma$-hybrid coordinate defined in a way that the model levels in the lower troposphere follow orography while the levels in the upper troposphere and stratosphere become approximate pressure coordinates with the last level at $0.01 \mathrm{hPa}$ or about $80 \mathrm{~km}$ altitude. The time step of the model is $\Delta t_{\text {atmosphere }}=450 \mathrm{~s}$, while the time step for transporting radiation through the atmosphere is $\Delta \mathrm{t}_{\text {radiation }}=1800 \mathrm{~s}$. The cumulus convection is parameterized with the mass flux transport (Tiedtke, 1989) using a modification for deep convection (Nordeng, 1994). The turbulent mixing of velocity, heat, humidity, and tracers is parameterized with vortex diffusion (Brinkop and Roeckner, 1995). For the concentration of greenhouse gases in all three numerical simulations, we always used the same RCP8.5 (Representative Concentration Pathways 8.5) climate scenario (Riahi et al. 2011) for the time during which our research was defined. Input data for RCP8.5 we took over from the global Coupled Model Intercomparison Project phase 5 (CMIP5) experiments based on the MPI-ESM earth system model of the Max Planck Institute for Meteorology (MPI-M, 2012).

We edited the JSBACH model (Reick et al., 2013) by including processes such as phenology, vegetation dynamics, vegetation albedo, and Bio-sphere-Energy-Transfer-Hydrology (BETHY) submodel. This model uses a mixed or mosaic approach (Koster and Suarez, 1992) in which each cell in the horizontal grid of the model is divided into tiles allowing the subnetwork representation of the extent of heterogeneity in the observed cell of the grid. The horizontal resolution is the same as in the ECHAM6 model, and each grid cell is divided into 11 tiles (Table 1). Each of the displayed tiles represents a specific CF and is connected with one of 21 Land Cover Type (LCT), or with 2 LCT if they have similar characteristics as is the case with tiles $3,4,7$, and 11, Table 2. It should be noted here that the LCT glacier was placed in combination with the LCT Tropical evergreen in tile 1 to simplify the operation of the model, Table 1.

Each tile in Table 1 represents a separate section that simulates the exchange of water, carbon, energy, and air movement between the land surface vegetation and atmosphere. These exchanges are summed for all tiles and presented as a total exchange for a single cell of the grid point. It was this way of presenting CF in the JSBACH model that enabled us to do our type of experiment, i.e., to examine whether there is an impact of vegetation cover on MST by replacing CF from 850 and 2050 in the area of the Pannonian Basin and if there is, how big of an impact is it.

It should be noted that for $\mathrm{CF}_{2002}$ forest and agricultural vegetation in the Pannonian Basin make up over $90 \%$ of the total CF both locally and regionally. That means it is the biggest changes of $\mathrm{CF}$ were made with $\mathrm{CF}_{850}$, and $\mathrm{CF}_{2050}$ in tiles $3,4,9$, and 11, Table 3 . Tiles type 1,2, and 6 are not contained in the region of the Pannonian Basin at all. While the tiles of type $5,7,8$, and 10 are contained significantly less part from the total part of CF and which amounts to $0.04 \%$, $0.64 \%, 0.36 \%$, and $1.85 \%$, respectively. Forest vegetation is mostly of the type "Temperate broad-leaf deciduous" and "Deciduous conifer," while agricultural vegetation is of type C3 and C4. The types of CF, as well as their percentage

Page 5/23 
representation outside the Pannonian Basin region, are the same for $\mathrm{CF}_{850}$ and $\mathrm{CF}_{2050}$ and were taken from the control period, i.e., from $\mathrm{CF}_{2002}$. Figure 2 gives an example of what the $\mathrm{CF}$ change for tile 4 looks like.

The data exchange between ECHAM6 and MPIOM models is performed every 24 hours, while the data exchange between ECHAM6 and JSBACH models is performed in each model time step defined in the ECHAM6 model and equals

$\Delta t_{\text {atmosphere }}=450 \mathrm{~s}$. Initial conditions required for the initialization of ECHAM6, JSBACH, and MPIOM models are the same for all three steps of our experiment. The data we used to initialize the starting conditions in the ECHAM6 and JSBACH models were taken over by the ECMWF ERA-Interim (Berrisford et al., 2011). To define the anthropogenic impact on surface vegetation change, we used data based on the land-use harmonization (LUH1) protocol developed by Hurtt et al., (2011), and are placed by MPI (Hagemann, 2002; Pongratz, J., et al., 2008).

\subsection{Trend}

To determine the trend for the increase or decrease of the MST, we used the method of least squares to determine the linear trend where the slope showed the average change over time. The linear trend is given by the equation

$$
Y=m \cdot t+c
$$

where the independent variable $t$ represents the time and the dependent variable $Y$ the phenomenon for which we define the trend, while $c$ and $m$ are our regression coefficients.

$$
\begin{gathered}
c=\frac{1}{N} \cdot\left(\sum_{i=1}^{N} Y_{i}-m \cdot \sum_{i=1}^{N} t_{i}\right) \\
m=\frac{N \cdot \sum_{i=1}^{N} t_{i} \cdot Y_{i}-\left(\sum_{i=1}^{N} t_{i}\right)\left(\sum_{i=1}^{N} Y_{i}\right)}{\sum_{i=1}^{N} t_{i}^{2}+\left(\sum_{i=1}^{N} t_{i}\right)^{2}}
\end{gathered}
$$

$N$ represents duration of the experiment, $N=10$ year and $i$ is counter of years. A standard statistical estimation of the output model data for $\mathrm{CF}_{2002}$ was done using the methods: Pearson Correlation Coefficient (R), root mean square error (RMSE), and mean bias (MB).

Applying the $\mathrm{MB}$ method to the results of the control experiment $\mathrm{CF}_{2002}$, we obtained the results from the model reanalysis of ERA-Interim for $\mathrm{MST}_{2 \mathrm{~m}}$ and $\mathrm{MST}_{\text {lev }}$. Therefore, every time we compared the results from $\mathrm{CF}_{850}$ and $\mathrm{CF}_{2050}$ with $\mathrm{CF}_{2002}$, we actually compared the results with the data from the given reanalysis.

The existence of a trend is determined using the Mann-Kendall test (Mann 1945, Kendall 1975), where we took a value for the level of significance $5 \%$.

\section{Result And Discussion}

\subsection{Statistical estimation of the output model data}

In Table 4, we present the results for MB, R, and RMSE from $\mathrm{CF}_{2002}$ for the decadal average of $\mathrm{MST}_{2 \mathrm{~m}}$ for JJA season. At the regional scale, $\mathrm{MB}$ is $-0.85^{\circ} \mathrm{C}$ and we noticed that is mostly negative both on a regional and local scale, which means that the model for this period gave us smaller results than the reanalysis. $\mathrm{R}$ is negative and indicates a lack of linear correlation between model values and reanalysis for the JJA season. After applying the MB method to the results with $\mathrm{CF}_{850}$ and $\mathrm{CF}_{2050}$, we obtained $\mathrm{R}$ with a weak negative linear correlation between the data. For RMSE, we found that it ranges around 1.8 at the regional scale, while at the local scale it ranges between 1.8 to 2.6, Table 4 . 


\subsection{Trend and decadal values of mean seasonal temperature}

For our research, we defined the trends of $\mathrm{MST}_{2 m}\left(\mathrm{Y}_{\mathrm{MST} 2 \mathrm{~m}}\right)$ whose values are shown through JJA season at the local and regional scale (Table 5) while the graphical presentation is given for local areas in Fig.3. At the regional scale (Fig. 7), $\mathrm{Y}_{\text {MST2m }}$ is negative as in most local areas, and this means that we mostly have a decrease in $\mathrm{MST}_{2 \mathrm{~m}}$. This reduction mainly occurs in the central and northern areas, while in the northern area it is more intense, i.e., there is a faster cooling of the air, Fig.3. As for the southern area, we mostly got a positive $\mathrm{Y}_{M S T 2 m}$, i.e., we have a warming of $\mathrm{MST}_{2 \mathrm{~m}}$. We only got a slight decrease in $\mathrm{MST}_{2 \mathrm{~m}}$ in $\mathrm{A} 4$, and an increase in $\mathrm{A} 5$ with $\mathrm{CF}_{2050}$. Using the MK test, the existence of the $\mathrm{Y}_{\text {MST2m, }}$ as well as it's decreasing and increasing, has been confirmed both at the local and regional scale for $\mathrm{CF}_{850}$ and $\mathrm{CF}_{2050}$.

As for the decadal average of $\mathrm{MST}_{2 m}$ (Table 6) at the regional scale, we obtained a temperature increase of about 1.5 ${ }^{\circ} \mathrm{C}$. With $\mathrm{CF}_{850}$, we got an increase of $1.7^{\circ} \mathrm{C}$ at the regional scale while at the local scale, it ranges between $0.6{ }^{\circ} \mathrm{C}$ and 2.6

${ }^{\circ} \mathrm{C}$. These increases are only for the southern area because we obtained a positive $\mathrm{Y}_{\text {MST2m }}$ for it (Fig.3), where there is an increasing trend of $\mathrm{MST}_{2 \mathrm{~m}}$. For the central and northern areas, there is a negative $\mathrm{Y}_{\mathrm{MST} 2 \mathrm{~m}}$ so, despite the increase we have received, there is a decreasing trend of $\mathrm{MST}_{2 \mathrm{~m}}$. While with $\mathrm{CF}_{2050}$, we got an increase of around $1.3^{\circ} \mathrm{C}$ at the regional scale, and this increase at the local scale ranges between $0.7^{\circ} \mathrm{C}$ to $1.8^{\circ} \mathrm{C}$. The difference of the decadal average of $\mathrm{MST}_{2 \mathrm{~m}}$ between $\mathrm{CF}_{850}$ and $\mathrm{CF}_{2050}$ for the $\mathrm{JJA}$ season ranges between $0.1{ }^{\circ} \mathrm{C}$ and $0.9{ }^{\circ} \mathrm{C}$ at the local and $0.4{ }^{\circ} \mathrm{C}$ at the regional scale, and we got a match in the northern area, Table 6.

We presented the decadal average of the $\mathrm{MST}_{\text {lev }}$ in Fig. 4 at 13 vertical levels which we showed over isobaric surfaces (air pressure) from 1000 to $700 \mathrm{hPa}$ with a vertical increment of $-25 \mathrm{hPa}$. On the isobaric surface of $1025 \mathrm{hPa}$, we presented the value of the decadal average of $\mathrm{MST}_{2 \mathrm{~m}}$. In the given figure it can be seen that the decadal average of $\mathrm{MST}_{\text {lev }}$ up to $900 \mathrm{hPa}$ of surface follows the temperature ratio as given with the decadal average of $\mathrm{MST}_{2 \mathrm{~m}}$ through season between $\mathrm{CF}_{850}$ and $\mathrm{CF}_{2050}$. While at levels higher than $900 \mathrm{hPa}, \mathrm{MST}_{\text {lev }}$ slowly equalizes between the $\mathrm{CF}_{850}$ and $\mathrm{CF}_{2050}$ experiments which is most pronounced in the northern area. The ratio of the differences we obtained for the decadal averages of $\mathrm{MST}_{2 \mathrm{~m}}$ (Table 6) between $\mathrm{CF}_{2002}$ with $\mathrm{CF}_{850}$ and $\mathrm{CF}_{2050}$ is very similarly represented for the decadal averages of $\mathrm{MST}_{\text {lev }}$ in the atmosphere layer between $1000 \mathrm{hPa}$ and $900 \mathrm{hPa}$ of the isobaric surface.

\subsection{Decadal values of aerodynamic roughness length and leaf area index}

The initial changes in $\mathrm{CF}$ concentrations that we performed for $\mathrm{CF}_{850}$ led to a significant change in the value of the aerodynamic roughness length $\left(z_{0}\right)$ at the regional and local scale, which is roughly increased between $50 \%$ and $85 \%$ (Table 7). For $\mathrm{CF}_{2050}$ this increase is much smaller and it is around $0 \%$ at the regional scale, while at the local scale we notice a slight decrease, mainly in the southern area, which is in line with the initial conditions for this step of our experiment. These changes in the $z_{0}$ are important because they indirectly affect the increase or decrease of the turbulent transport of fluxes from the surface to the atmosphere, (Giorgetta et al., 2013a,b). Also, the higher $z_{0}$ at the Earth's surface reduces the wind speed (Rotenberg and Yakir, 2010; Vautard et al. 2010) and thus the preconditions for increasing turbulent transport.

The inclusion of vegetation dynamic and phenology module in the JSBACH model was a condition to obtain the production of leaf area index (LAl) which is very important in defining surface albedo (Otto et al., 2011). The increase in LAI was obtained with $\mathrm{CF}_{850}$ (Table 8) at both local and regional scale and is approximately between $1.5 \%$ and $13 \%$ at the local scale, and $6 \%$ at the regional. With $\mathrm{CF}_{2050}$, we generally recorded a reduced $\mathrm{LAl}$ of $1.1 \%$ to $7 \%$ at the local scale and $3 \%$ at the regional. 


\subsection{Trends of albedo and surface sensible heat flux}

Numerous studies with climate models indicate that temperate-type forests cool the air compared to areas where there are pastures or agricultural plantations, while other studies show the opposite (Jackson et al., 2008 and Anav et al., 2010). Some of these contradictions may be related to the season, water availability, and soil moisture levels. In our research, we got a heating trend only in the southern area, while in the central and northern areas, we have a cooling trend (Fig. 3).

One of the ways of heating the ground layer of air with the forests of temperate type is to distribute more heat in the atmosphere because they are darker and absorb more sunlight, i.e., they have a small albedo and heat the air through the radiation, conduction, and convection (Lee et al., 2011). For this type of forest, albedo ranges from 0.15 to 0.18 (Barry and Chorley, 1992), which means that between $15 \%$ and $18 \%$ of the total incoming solar radiation returns to the atmosphere. In our research, we obtained values of albedo, which at the regional scale is approximately $12.7 \%$ for the JJA season. These changes in albedo that we obtained in our experiments are directly related to the distribution of the surface sensible heat flux (sshf), Fig. 5, as one of the key processes by which forests can modify air temperature. This can be seen in Fig. 3 for the JJA season where the slope of trend $Y_{M S T 2}$ is very similar to the slope of trend sshf $\left(Y_{\text {sshf }}\right)$, Fig.5, and especially in the northern area where this similarity is most pronounced.

However, if we look at the trend of albedo $\left(\mathrm{Y}_{\text {albedo }}\right)$ in Fig. 6 we see that with $\mathrm{CF}_{2050}$ it's mostly slightly negative on the local and regional scale (Fig. 7), i.e. tends to reduce albedo. While with $\mathrm{CF}_{850}$ for the JJA season we got that $Y_{\text {albedo }}$ is positive, Fig. 6, where it is most pronounced in the northern and central area. In the south area, this trend is very slight which again agrees well with $\mathrm{Y}_{\text {MST2m }}$ and $\mathrm{Y}_{\text {MSTlev }}$ for these areas and regions.

In the JJA season albedo has a significant role in the regulation of surface air heating via sshf because these two trends are mostly negatively linearly correlated. That is when $\mathrm{Y}_{\text {albedo }}$ increases $\mathrm{Y}_{\text {sshf }}$ decreases and vice versa. But here appears the second process that cools the ground air, because of an indirect increase in albedo which we got with $\mathrm{CF}_{850}$. In the JJA season, we have an increase of albedo but due to an increase in vegetation cover, we should have a decrease in albedo and thus heating of surface air.

This happens due to the increase of cloudiness above the forest areas (Arneth et al., 2010) and consequently, we got an increase in cloud albedo, and thus the surface albedo which further causes a decrease in surface air heating.

With $\mathrm{CF}_{850}$ and $\mathrm{CF}_{2050}$, we got a positive trend of cloud cover for the northern area, while for the central area it is mostly slightly positive with $\mathrm{CF}_{2050}$ and slightly negative with $\mathrm{CF}_{850}$ which is in line with the trends of albedo and $\mathrm{MST}_{2 \mathrm{~m}}$. This increase in cloudiness over forest covers during the summer season is in line with the results they have obtained (Teuling et al., 2017).

For the trend of $\mathrm{MST}_{2 \mathrm{~m}}$ cooling that we got at the regional scale during the JJA season (Fig. 7), we can say that it mainly happens due to the changes of forest cover of temperate type, because we made in the central and northern area an increase of $30 \%$ to $60 \%$ while for the southern area this increase is between $15 \%$ and $25 \%$ for $\mathrm{CF}_{850}$, Table 3 . For $\mathrm{CF}_{2050}$, this increase is significantly smaller and ranges from $2 \%$ to $10 \%$ in the northern area, and for central and southern areas, it ranges from $1 \%$ to $3 \%$. Tölle et al., (2018) also recorded air cooling during the summer and warming during the winter season for mid-Europe due to the influence of increasing forest cover in their research. This cooling effect we obtained is consistent with remote and surface observations in Central Europe (Alkama and Cescatti, 2016; Bright et al., 2017). Using satellite data for approximately the same period, (Tang et al., 2018) showed that there is a difference between areas under forest vegetation and open land on seasonal variations of maximum and minimum surface air temperatures on the European continent. That is, forest areas have a trend of cooling the surface air 
temperature during the summer season and warming it during the winter. They also showed that these trends are increasing as we go from low to high latitudes, which is in line with our results because we also got a bigger trend of cooling in the northern than in the central area for the summer season, Fig. 3. While for the southern area we got a warming trend which is again in line with Tölle et al., (2018) and their results for surface air heating in southern Europe due to the increase of forest cover. For similar seasonal period Heck et al. (2001) have concluded that an increase in forest cover leads to a cooler spring and warmer summer which are partially contradictory with our results, that is, we obtained that in the summer season there was warming but with a tendency of further cooling.

\section{Conclusion}

The change in the concentration of CF types that we performed in our study unequivocally shows that it led to a change in $\mathrm{MST}_{2 \mathrm{~m}}$ and $\mathrm{MST}_{\text {lev }}$ both at the local and regional scales. These changes are caused by a change in the energy balance on the surface that we obtained as a result of a decrease and increase in albedo. This increase in albedo is caused by a significant increase in forest cover and a decrease in agricultural and grass regions with $\mathrm{CF}_{850}$, while this change is smaller with $\mathrm{CF}_{2050}$. Due to the change, we have made in $\mathrm{CF}$, there was a change in the surface energy balance caused by the changes in transport of the flux of sensible heat from the surface layers into the atmosphere. Depending on the area this led to a tendency of heating or cooling of surface air for the summer season. We got a cooling trend in the northern region of the Pannonian basin which is also the largest and amounts $-0.3\left[{ }^{0} \mathrm{C} /\right.$ year $]$. In the central area, we also got a cooling trend but it is less intense and amounts to about $-0.1\left[{ }^{0} \mathrm{C} /\right.$ year], while we got a warming trend in the southern region which amounts to about $0.1\left[{ }^{0} \mathrm{C} / \mathrm{year}\right]$. At the regional scale, we also got a trend of surface air cooling of approx $-0.1{ }^{0} \mathrm{C} /$ year] . The cooling effect that we got for the summer season is mainly due to the increase in albedo, which occurs due to the increase in cloudiness above the areas covered with temperate-type forest vegetation and is consistent with recent research on the subject.

\section{Declarations}

Funding (this research is not funded by any institution or organization)

Conflicts of interest (the authors declare no conflict of interest)

Availability of data and material (Not applicable)

Code availability (Not applicable)

Ethics approval (we all approvals)

Consent to participate (we all approvals)

Consent for publication (we all approvals)

\section{Acknowledgements}

We acknowledge Republic Hydro-meteorological Service of Serbia (RHMSS) for providing the meteorological observation data.

\section{Contributions}


Albert Ruman: numerical and graphical data processing, text of the research

Anna Ruman: data collection, text of the research

\section{References}

Alkama R. and Cescatti A. (2016) Biophysical climate impact of recent changes in global forest cover. Science 351, 600-604. doi: 10.1126/science.aac8083.

Anav A, Ruti P.M., Artale V. and Valentini R., (2010) Modelling the effects of land-cover changes on surface climate in the Mediterranean region. Clim. Res., 41, 91-104.

Arakawa A. and Lamb V.R., (1977) Computational design of the basic dynamical processes of the UCLA general circulation model. Methods Comput. Phys., 17, 173-265.

Arneth A., Sitch S., Bondeau A., Butterbach-Bahl K., Foster P., Gedney N., de Noblet-Ducoudré N., Prentice I.C., Sanderson M., Thonicke K., Wania R. and Zaehle S., (2010) From biota to chemistry and climate: towards a comprehensive description of trace gas exchange between the biosphere and atmosphere, Biogeosciences, 7, 121-149.

Balla G., Caldeira K., Wickett M., Phillips T.J., Lobell D.B., Delire C. and Mirin, A., (2007) Combined climate and carboncycle effects of large-scale deforestation. Proc. Natl. Acad. Sci., 104, 6550-6555.

Barry R.G. and Chorley R.J., (1992) Atmosphere, Weather \& Climate, 6th edn. Routledge, London. 392pp.

Bastos A., Gouveia M.C., Trigo M.R., and Running W.S. (2013) Analysing the spatio-temporal impacts of the 2003 and 2010 extreme heatwaves on plant productivity in Europe. Biogeosciences, 11, 3421-3435, 2014, doi:10.5194/bg-113421-2014.

Berrisford P, Dee D.P., Poli P., Brugge R., Fielding K., Fuentes M., Kållberg P.W., Kobayashi S., Uppala S., Simmons A., (2011) The ERA interim archive, ttp://www.ecmwf.int/publications/.

Betts R.A., (2006) Forcings and feedbacks by land ecosystem changes on climate change. J. Phys. IV France, 139, 123146, doi:10.1051/jp4:2006139009.

Betts A.K. and Ball J.H., (1997) Albedo over the boreal forest. J. Geophys. Res., 102, 28901-28910, doi:10.1029/96JD03876.

Bevan L.S., Los O.S., and North J.R.P. (2013) Response of vegetation to the 2003 European drought was mitigated by height. Biogeosciences, 11, 2897-2908, 2014,

doi:10.5194/bg-11-2897-2014.

Bonan G.B., (2008) Forests and Climate Change: Forcings, Feedbacks and the Climate Benefits of Forests. Science 320, 1444. doi:10.1126/science.1155121.

Bright R., Davin E., O'Halloran T. et al. Local temperature response to land cover and management change driven by nonradiative processes. Nature Clim Change 7, 296-302 (2017). https://doi.org/10.1038/nclimate3250.

Brinkop S. and Roeckner E. (1995) Sensitivity of a general circulation model to parameterizations of cloud-turbulence interactions in the atmospheric boundary layer. Tellus, 47A, 197-220. 
Claussen M., Brovkin V., and Ganopolski, A.: Biogeophysical versus biogeochemical feedbacks of large-scale land cover change, Geophys. Res. Lett., 28, 1011-1014, 2001

Copernicus Marine Service (CMS). https://marine.copernicus.eu/

Ellison D., Futter M. and Bishop K. (2012) On the fores cover - water yield debate: From demand-to supply-side thinking. Glob. Change Biol., 18, 2677-2680, doi:10.1111/j.1365-2486.2012.02703.x.

Giorgetta A.M,, Roeckner E.,, Mauritsen T.,, Stevens B., Bader J., Crueger T., Esch M., Rast S., Kornblueh L., Schmidt H., Kinne S., Möbis B., Krismer T., (2013a) The atmospheric general circulation model ECHAM6, Model description. Tehnical note, Reports on Earth System Science, ISSN 1614-1199.

Giorgetta A.M., et al. (2013b), Climate and carbon cycle changes from 1850 to 2100 in MPI-ESM simulations for the Coupled Model Intercomparison Project phase 5, J. Adv. Model. Earth Syst., 5, 572-597, doi:10.1002/jame.20038.

Hagemann S. (2002) An improved land surface parameter, dataset for global and regional climate models, Max Planck Institute for Meteorology, Report 336.

Heck P., Lüthi D., Wernli H. and Schär C. (2001) Climate impacts of European-scale anthropogenic vegetation changes: A sensitivity study using a regional climate model. J. Geophysics Research, https://doi.org/10.1029/2000JD900673.

Hurtt G.C., et al. (2011), Harmonization of land-use scenarios for the period 1500-2100: 600 years of global gridded annual land-use transitions, wood harvest, and resulting secondary lands, Clim. Change, 109, 117-161, doi:10.1007/s10584-011-0153-2.

Jackoson R.B., et al., (2008). Protecting climate with forests. Environ. Res. Lett. 3, 044006, doi:10.1088/17489326/3/4/044006.

Jeuken A., Siegmund P., Heijboer L., Feichter J., and Bengtsson L. (1996) On the Potential of assimilating meteorological analyses in a global climate model for the purposes of model validation, J.Geophys. Res., 101, 16 939-16 950, 1996.

Kendall M. G. (1975) Rank Correlation Methods. New York, NY: Oxford University Press.

Koster R.D., and Suarez J.M., (1992) A comparative analysis of two land surface heterogeneity representations, J. Clim., 5, 1379-1390, American Meteorological Society.

Krishnamurti N.T., Xue J., Bedi S.H., Ingles K. and D. Oosterhof (1991). Physical initialization for numerical weather prediction over the tropics. Tellus, 43AB:53-81, 1991.

Lee X., Goulden M.L, Hollinger Y.D, et al., (2011) Observed increase in local cooling effect of deforestation at higher latitudes. Nature, 479, 384-387, doi:10.1038/nature10588.

Lohmann U. and Hoose C. (2009) Sensitivity studies of different aerosol indirect effects in mixed-phase clouds, Atmos. Chem. Phys., 9, 8917-8934, doi:10.5194/acp-9-8917-2009, 2009.

Mann H. B. (1945). Nonparametric tests against trend. Econometrica 13, 245-259. doi: 10.2307/1907187

MPI-M (Max-Planck-Institut für Meteorologie), Deutsches Klimarechenzentrum (2012). External input data for CMIP5 experiments based on the MPI-ESM earth system model of the Max Planck Institute for Meteorology. World Data Center for Climate (WDCC) at DKRZ. http://cera-www.dkrz.de/WDCC/ui/Compact.jsp?acronym=CMIP5_MPI-ESM_input 
Nordeng T.E. (1994) Extended versions of the convective parameterization scheme at ECMWF and their impact on the mean and transient activity of the model in the tropics. Technical Memorandum 206, ECMWF, Reading, UK.

Otto J., Raddatz T., Claussen M. (2011) Strength of forest-albedo feedback in mid-Holocene climate simulations. Clim. Past, 7, 1027-1039, 2011, doi:10.5194/cp-7-1027-2011.

Pielke R.A., Adegoke J., Beltran-Przekurat A., Hiemstra C.A., Lin J., Nair U.S., Niyogi D. and Nobis T.E., (2007) An overview of regional land-use and landcover impacts on rainfall. Tellus, 59, 587-601, doi:10.1111/j.1600-0889.2007.00251.x.

Pitman A. J., Cruz T.F., Brovkin V., de Noblet-Ducoudre N., et al., (2009) Uncertainties in climate responses to past land cover change: First results from the LUCID intercomparison study. Geophys. Res. Lett., 36, L14814, doi:10.1029/2009GL039076.

Pongratz J. et al. (2008) A reconstruction of global, agricultural areas and land cover for the last millennium. Global Biogeochem. Cycles, 22, GB3018, doi:10.1029/2007GB003153.

Pongratz J., Raddatz T., Reick H.C., Esch M., and Claussen M. (2009) Radiative forcing from anthropogenic land cover change since A.D. 800, Geophys. Res. Lett., 36, L02709, doi:10.1029/2008GL036394.

Port U., Brovkin V., and Claussen M. (2012) The influence of vegetation dynamics on anthropogenic climate change. Earth Syst. Dynam., 3, 233-243, 201, doi:10.5194/esd-3-233-2012.

Rast S., Brokopf R., Cheedela S-K., Esch M., Gayler V., Kirchner I., Kornblüh L., Rhodin A., Schmidt H., Schulzweida U., Wieners K-H. (2013) User manual for ECHAM6. Reports on Earth System Science ISSN 1614-1199 June 21, 2013, (201302-26), version echam-6.1.06p3-guide-1.3.

Reick C.H., Raddatz T., Brovkin V., and Gayler V. (2013) Representation of natural and anthropogenic land cover change in MPI-ESM, J. Adv. Model. Earth Syst., 5, 459-482, doi:10.1002/jame.20022.

Riahi K., Krey V., Rao S., Chirkov V., Fischer G., Kolp P., Kindermann G., Nakicenovic N., Rafai P. (2011) RCP-8.5 Exploring the consequence of high emission trajectories, Clim. Change, 109, 33-57, doi:10.1007/s10584-011-0149-y.

Rotenberg E. and Yakir D., (2010) Contribution of semi-arid forests to the climate system. Science, 327, 451-454.

Sanchez E., Gaertner M.A., Gallardo C., Padorno E., Arribas, A. and Castro, M., (2007) Impacts of a change in vegetation description on simulated European summer present-day and future climates. Clim. Dyn., 29, 319-332.

Schneck R. and Mosbrugger V., (2011) Simulated climate effects of Southeast Asian deforestation: Regional processes and teleconnection mechanisms. J. Geophys. Res., 116, D11116, doi:10.1029/2010JD015450.

Stéfanon M., Drobinski P., D’Andrea F., and de Noblet-Ducoudré N., (2012) Effects of interactive vegetation phenology on the 2003 summer heat waves. JOURNAL OF GEOPHYSICAL RESEARCH, VOL. 117, D24103, doi:10.1029/2012JD018187, 2012.

Stevens B., Giorgetta M., Esch M., Rast S., et al., (2013) Atmospheric component of the MPI-M Earth System Model: ECHAM6, J. Adv. Model. Earth Syst., 5, 146-172, doi:10.1002/jame.20015.

Tang B., Zhao X. and Zhao W. (2018) Local Effects of Forests on Temperatures across Europe. Remote Sens. 2018, 10, 529; doi:10.3390/rs10040529. 
Teuling A.L., Seneviratne I.S. et al., (2010) Contrasting response of European forest and grassland energy exchange to heatwaves. Nature Geosci., 3, 722-727, doi:10.1038/ngeo950.

Teuling A.L., et al., 2010: Contrasting response of European forest and grassland energy exchange to heatwaves. Nature Geosci., 3, 722-727, doi:10.1038/ngeo950.

Teuling A.L., Taylor M.C., et al., (2017) Observational evidence for cloud cover enhancement over western European forests. J. NATURE COMMUNICATIONS, 8:14065, doi:10.1038/ncomms14065.

Tiedtke M. (1989). A comprehensive mass flux scheme for cumulus parameterization in large-scale models, Mon. Weather Rev., 117(8), 1779-1800.

Tölle H.M, Brell M, Radtke K and Panitz H-J (2018) Sensitivity of European Temperature to Albedo Parameterization in the Regional Climate Model COSMO-CLM Linked to Extreme Land Use Changes. Front. Environ. Sci., 20 November 2018, https://doi.org/10.3389/fenvs.2018.00123

Valcke S., (2013) The OASIS3 coupler: a European climate modelling community software, Geosci. Model Dev., 6, 373388, doi:10.5194/gmd-6-373-2013.

Vautard R., Cattiaux J., Yiou P., Jean-Noël Thépaut, Ciais P. (2010) Northern Hemisphere atmospheric stilling partly attributed to an increase in surface roughness. NATURE GEOSCIENCE. doi:10.1038/NGEO979.

Wetzel P., Haak H., Jungclaus J. and Maier-Reimer E., (2011) Tehnical Note: The Max-Planck-Institute Global Ocean/SeaIce Model MPI-OM.

Wulfmeyer V., Flamant C., Behrendt A., Blyth A., Brown A., Dorninger M., Illingworth A., Mascart P., Montani A. and Weckwerth T., (2011) Advances in the understanding of convective processes and precipitation over low-mountain regions through the Convective and Orographically-induced Precipitation Study (COPS). Q. J. R. Meteorol. Soc., 137, 12. doi:10.1002/qj.799.

\section{Tables}

Table 1 Cover Fraction (CF) for JSBACH model 


\begin{tabular}{|ll|}
\hline Tiles & Cover Fraction \\
\hline 1 & Tropical evergreen + Glacier \\
\hline 2 & Tropical deciduous \\
\hline 3 & Temperate broad-leaf evergreen + Evergreen conifer \\
\hline 5 & Temperate broad-leaf deciduous + Deciduous conifer \\
\hline 6 & Daingreen shrub \\
\hline 7 & C3 grass + Tundra \\
\hline 9 & C4 grass \\
\hline 10 & C3 pasture \\
\hline 11 & C3 crop + C4 crop \\
\hline
\end{tabular}

Table 2 Land Cover Types (LCT) which are represented in the JSBACH model

\begin{tabular}{|llcl|}
\hline Num. & Land Cover Type & Num. & Land Cover Type \\
\hline 1 & Glacier & 12 & C3 grass \\
\hline 2 & Tropical evergreen & 13 & C4 grass \\
\hline 3 & Tropical deciduous & 14 & Pasture \\
\hline 4 & Extra-tropical evergreen & 15 & C3 pasture \\
\hline 5 & Extra-tropical deciduous & 16 & C4 pasture \\
\hline 7 & Temperate broad-leaf evergreen & 17 & Tundra \\
\hline 8 & Temperate broad-leaf deciduous & 18 & Swamp \\
\hline 9 & Deciduous conifer & 19 & Crop \\
\hline 10 & Raingreen shrub & 20 & C3 crop \\
\hline 11 & Deciduous shrub & 21 & C4 crop \\
\hline
\end{tabular}

Table 3 Percentage of the type of CF in tile 4 (Temperate broad-leaf deciduous + Deciduous conifer), tile 9 (C3 pasture) and tile 11 (C3 crop + C4 crop) 


\begin{tabular}{|lllllllllll|}
\hline Area & Tiles 4 & & \multicolumn{5}{c}{ Tiles 9} \\
& $\mathrm{CF}_{2002}$ & $\mathrm{CF}_{0850}$ & $\mathrm{CF}_{2050}$ & $\mathrm{CF}_{2002}$ & $\mathrm{CF}_{0850}$ & $\mathrm{CF}_{2050}$ & $\mathrm{CF}_{2002}$ & $\mathrm{CF}_{0850}$ & $\mathrm{CF}_{2050}$ \\
\hline A1 & 57.92 & 79.73 & 59.30 & 5.68 & 1.67 & 4.77 & 29.86 & 8.64 & 29.51 \\
\hline A2 & 49.16 & 77.10 & 50.73 & 6.21 & 1.78 & 5.37 & 37.71 & 10.48 & 37.17 \\
\hline A3 & 40.10 & 65.86 & 40.74 & 5.88 & 2.64 & 5.52 & 45.34 & 10.78 & 45.16 \\
\hline A4 & 39.94 & 65.82 & 40.47 & 5.80 & 2.72 & 5.37 & 44.44 & 8.45 & 44.44 \\
\hline A5 & 54.94 & 84.71 & 56.41 & 5.08 & 1.45 & 4.13 & 32.76 & 5.59 & 32.42 \\
\hline A6 & 35.90 & 78.36 & 37.49 & 6.57 & 2.01 & 5.64 & 53.10 & 8.56 & 52.67 \\
\hline A7 & 20.21 & 52.55 & 21.00 & 5.83 & 2.32 & 5.14 & 63.50 & 9.87 & 63.41 \\
\hline A8 & 26.75 & 56.14 & 27.49 & 4.91 & 1.93 & 4.20 & 55.43 & 7.46 & 55.43 \\
\hline A9 & 36.15 & 77.16 & 38.03 & 5.71 & 1.70 & 4.59 & 48.27 & 5.10 & 47.44 \\
\hline A10 & 28.75 & 77.82 & 32.73 & 5.54 & 2.00 & 4.03 & 61.31 & 6.42 & 58.35 \\
\hline A11 & 32.16 & 69.72 & 36.15 & 4.98 & 1.62 & 3.09 & 55.30 & 5.89 & 52.47 \\
\hline A12 & 34.04 & 72.17 & 37.11 & 5.19 & 1.54 & 3.54 & 52.52 & 5.47 & 49.97 \\
\hline Region & 41.28 & 73.84 & 43.23 & 5.54 & 1.93 & 4.49 & 45.14 & 7.38 & 43.97 \\
\hline
\end{tabular}

Table 4 Mean deviation (MB), Pearson correlation coefficient (R), and root mean square error (RMSE) for the decadal average mean summer seasonal temperature $\left(\mathrm{MST}_{2 \mathrm{~m}}\right)$ from control experiment $\mathrm{CF}_{2002}$

\begin{tabular}{|lllllllllllllll|}
\hline & A1 & A2 & A3 & A4 & A5 & A6 & A7 & A8 & A9 & A10 & A11 & A12 & Region \\
\hline MB & 0.62 & 1.05 & -0.15 & -1.74 & -0.65 & -0.92 & -1.24 & -1.62 & -1.87 & -1.54 & -0.93 & -1.52 & -0.85 \\
\hline R & 0.14 & 3.10 & -0.14 & -0.26 & 0.07 & -0.02 & -0.13 & -0.18 & -0.09 & -0.13 & -0.14 & -0.06 & -0.07 & \\
RMSE & 1.81 & 2.17 & 1.96 & 2.57 & 1.75 & 2.11 & 2.33 & 2.41 & 2.38 & 2.23 & 1.89 & 2.10 & 1.79 & \\
\hline
\end{tabular}

Table 5 Trend of the mean summer seasonal surface air temperature $\left(\mathrm{Y}_{\mathrm{MST} 2 \mathrm{~m}}\left[{ }^{0} \mathrm{C} /\right.\right.$ year $]$,)

\begin{tabular}{|lllllllllllllll|}
\hline & $\mathrm{A} 1$ & $\mathrm{~A} 2$ & $\mathrm{~A} 3$ & $\mathrm{~A} 4$ & $\mathrm{~A} 5$ & $\mathrm{~A} 6$ & $\mathrm{~A} 7$ & $\mathrm{~A} 8$ & $\mathrm{~A} 9$ & $\mathrm{~A} 10$ & $\mathrm{~A} 11$ & A12 & Region \\
\hline $\mathrm{CF}_{2002}$ & -0.03 & 0.01 & 0.02 & 0.02 & -0.05 & -0.04 & -0.02 & 0.01 & -0.08 & -0.05 & -0.03 & 0.01 & -0.02 \\
$\mathrm{CF}_{850}$ & 0.05 & 0.09 & 0.11 & 0.14 & -0.11 & -0.11 & -0.09 & -0.03 & -0.36 & -0.31 & -0.25 & -0.16 & -0.08 \\
$\mathrm{CF}_{2050}$ & 0.28 & 0.23 & 0.09 & -0.03 & 0.06 & -0.02 & -0.15 & -0.24 & -0.03 & -0.03 & -0.35 & -0.36 & -0.09 \\
\hline
\end{tabular}

Table 6 Decadal average of mean summer seasonal near-surface air temperature (MST $2 \mathrm{~m})$ 


\begin{tabular}{|llllllllllllll|}
\hline & A1 & A2 & A3 & A4 & A5 & A6 & A7 & A8 & A9 & A10 & A11 & A12 & Region \\
\hline $\mathrm{CF}_{2002}$ & 21.8 & 20.7 & 20.8 & 21.2 & 19.7 & 21.6 & 21.7 & 21.1 & 18.4 & 19.4 & 19.3 & 19.5 & 20.1 \\
\hline $\mathrm{CF}_{850}$ & 23.6 & 23.0 & 23.4 & 23.9 & 21.0 & 22.8 & 23.5 & 23.0 & 19.0 & 20.2 & 20.3 & 20.6 & 21.8 \\
\hline $\mathrm{CF}_{2050}$ & 22.9 & 22.2 & 22.5 & 23.0 & 20.4 & 22.3 & 23.0 & 22.4 & 19.1 & 20.2 & 20.3 & 20.6 & 21.4 \\
\hline
\end{tabular}

Table 7 Decadal average of aerodynamic roughness length $\left(z_{0}\right)$

\begin{tabular}{|llllllllllllll|}
\hline & $\mathrm{A} 1$ & $\mathrm{~A} 2$ & $\mathrm{~A} 3$ & $\mathrm{~A} 4$ & $\mathrm{~A} 5$ & $\mathrm{~A} 6$ & $\mathrm{~A} 7$ & $\mathrm{~A} 8$ & $\mathrm{~A} 9$ & $\mathrm{~A} 10$ & $\mathrm{~A} 11$ & $\mathrm{~A} 12$ & Region \\
\hline $\mathrm{CF}_{2002}$ & 1.28 & 1.03 & 0.83 & 0.81 & 1.23 & 0.66 & 0.37 & 0.54 & 0.81 & 0.52 & 0.62 & 0.68 & 0.87 \\
\hline $\mathrm{CF}_{850}$ & 1.67 & 1.47 & 1.21 & 1.21 & 1.69 & 1.27 & 0.84 & 0.98 & 1.48 & 1.26 & 1.19 & 1.29 & 1.34 \\
$\mathrm{CF}_{2050}$ & 1.23 & 1.00 & 0.80 & 0.78 & 1.20 & 0.64 & 0.34 & 0.52 & 0.83 & 0.59 & 0.69 & 0.74 & 0.87 \\
\hline
\end{tabular}

Table 8 Decadal average of leaf area index (LAl)

\begin{tabular}{|llllllllllllll|}
\hline & $\mathrm{A} 1$ & $\mathrm{~A} 2$ & $\mathrm{~A} 3$ & $\mathrm{~A} 4$ & $\mathrm{~A} 5$ & $\mathrm{~A} 6$ & $\mathrm{~A} 7$ & $\mathrm{~A} 8$ & $\mathrm{~A} 9$ & $\mathrm{~A} 10$ & $\mathrm{~A} 11$ & A12 & Area \\
\hline $\mathrm{CF}_{2002}$ & 2.66 & 2.58 & 2.53 & 2.60 & 2.76 & 2.52 & 2.34 & 2.50 & 2.57 & 2.53 & 2.56 & 2.66 & 2.60 \\
\hline $\mathrm{CF}_{850}$ & 2.76 & 2.66 & 2.57 & 2.64 & 2.94 & 2.67 & 2.39 & 2.55 & 2.91 & 2.81 & 2.72 & 2.83 & 2.76 \\
\hline $\mathrm{CF}_{2050}$ & 2.52 & 2.41 & 2.35 & 2.44 & 2.71 & 2.37 & 2.14 & 2.34 & 2.63 & 2.50 & 2.49 & 2.59 & 2.52 \\
\hline
\end{tabular}

Figures 


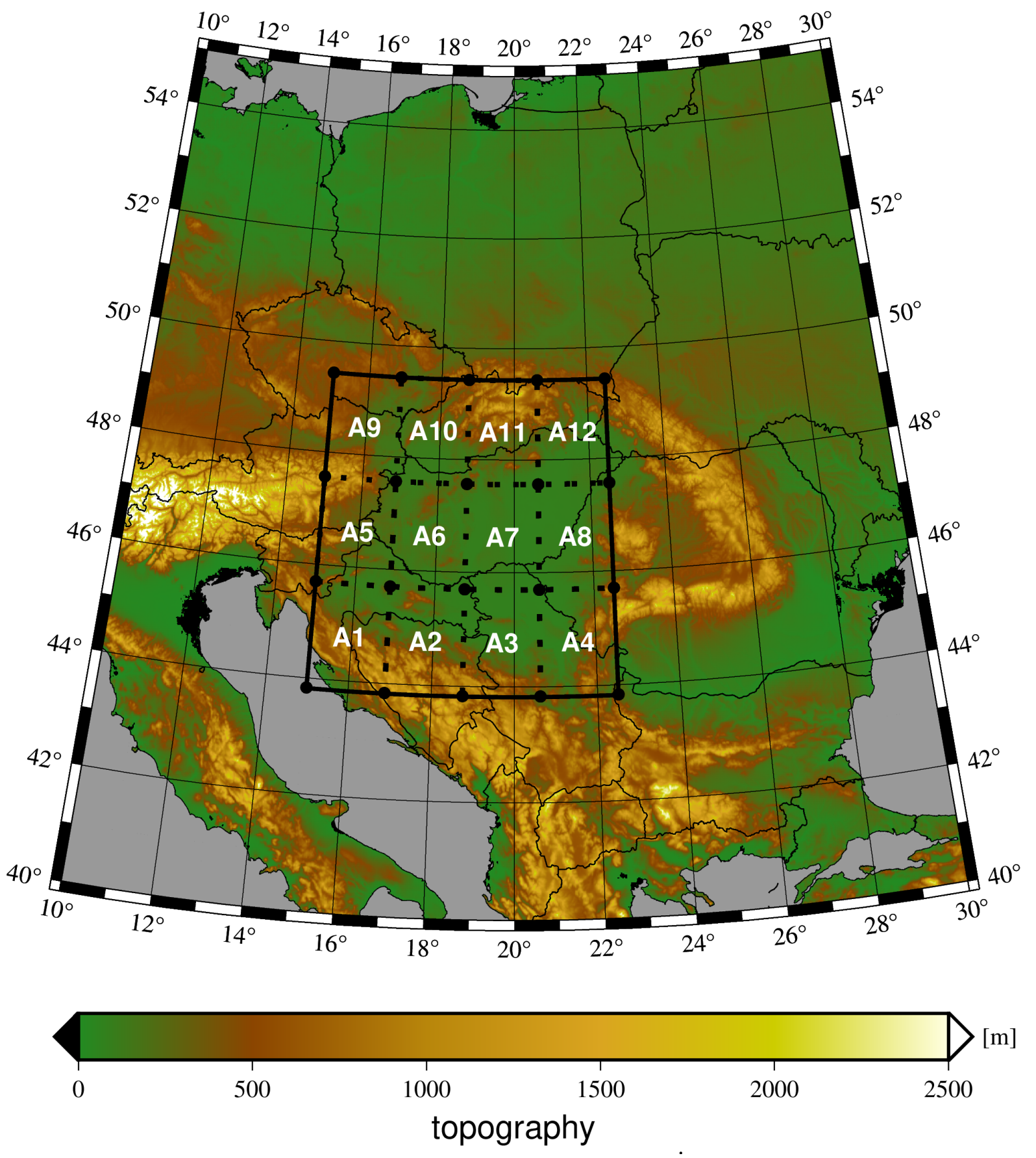

Figure 1

Geographical position of the Pannonian Basin region with local areas marked with: A1, A2,....., A11 and A12. Note: The designations employed and the presentation of the material on this map do not imply the expression of any opinion whatsoever on the part of Research Square concerning the legal status of any country, territory, city or area or of its authorities, or concerning the delimitation of its frontiers or boundaries. This map has been provided by the authors. 
a.1)
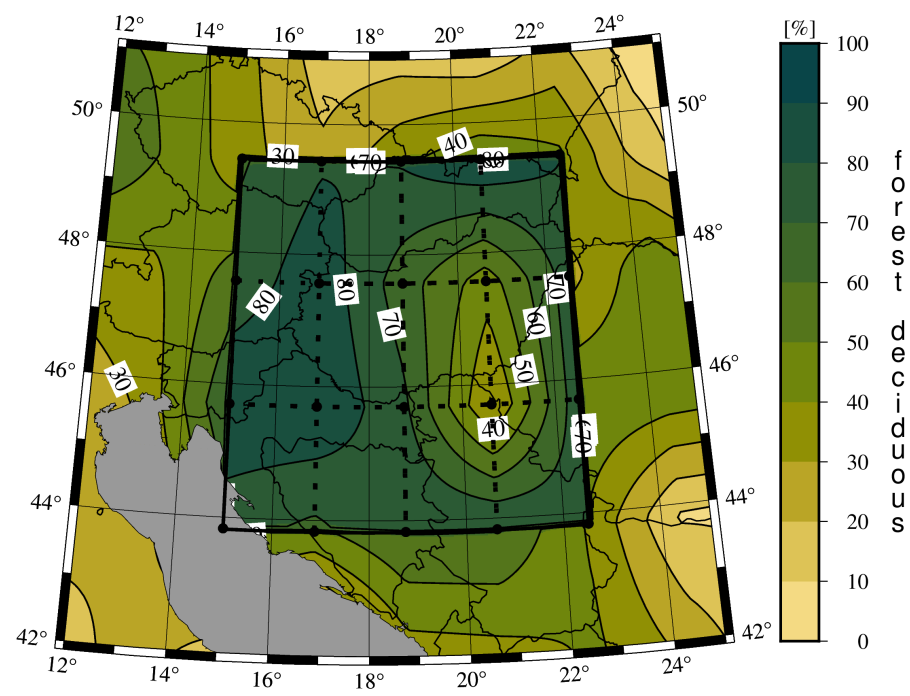

b.1)
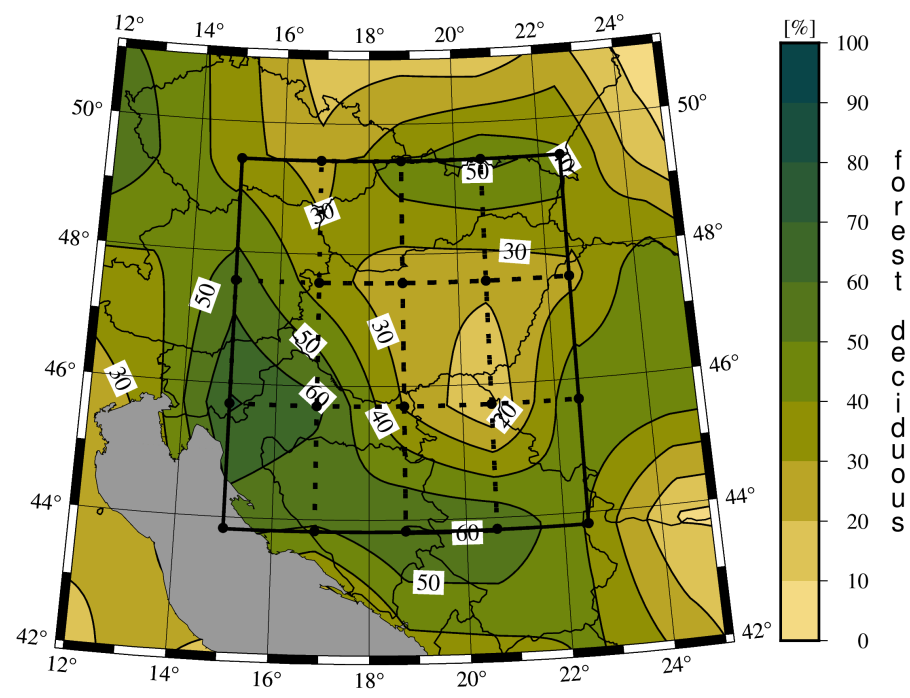

a.2)

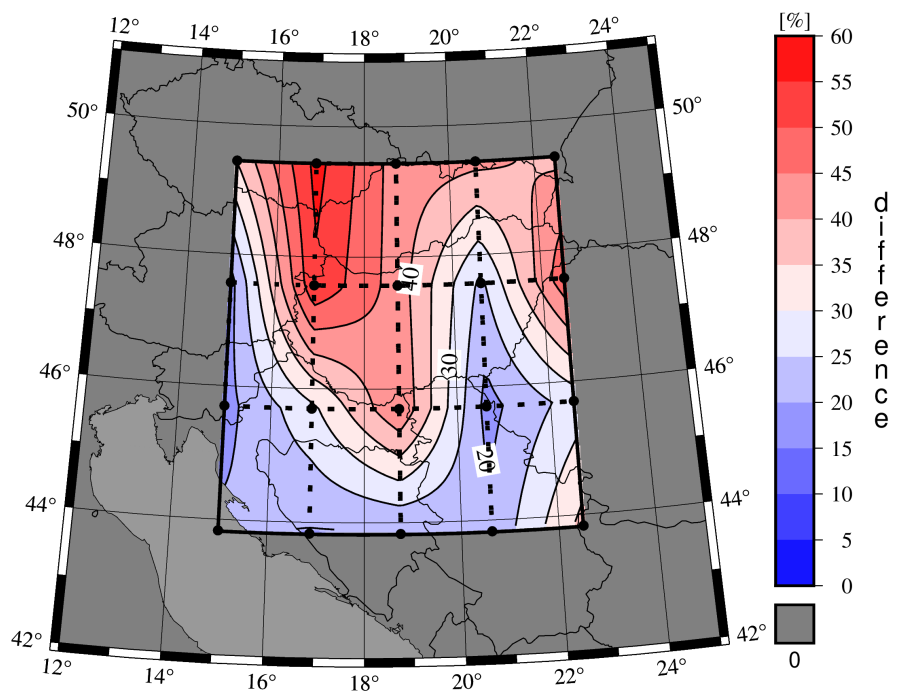

b.2)

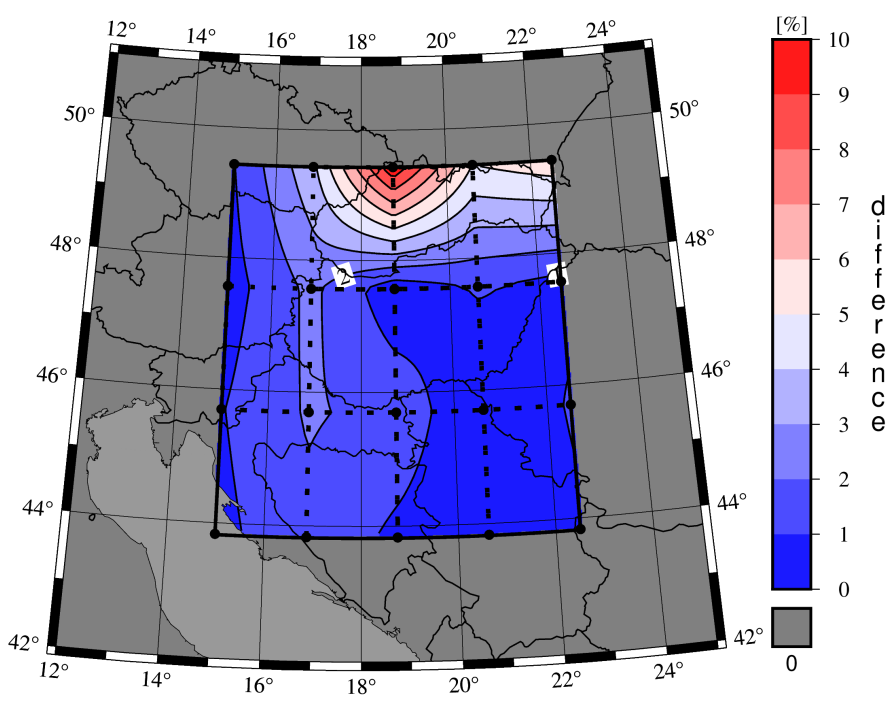

\section{Figure 2}

Change of cover fraction (CF) for tile 4. Change in the second step of the experiment (CF850) a.1, difference CF850, and control the experiment (CF2002) a.2. Change CF in the third step of the experiment (CF2050) b.1, difference CF2050 and CF2002 b.2. Note: The designations employed and the presentation of the material on this map do not imply the expression of any opinion whatsoever on the part of Research Square concerning the legal status of any country, territory, city or area or of its authorities, or concerning the delimitation of its frontiers or boundaries. This map has been provided by the authors. 

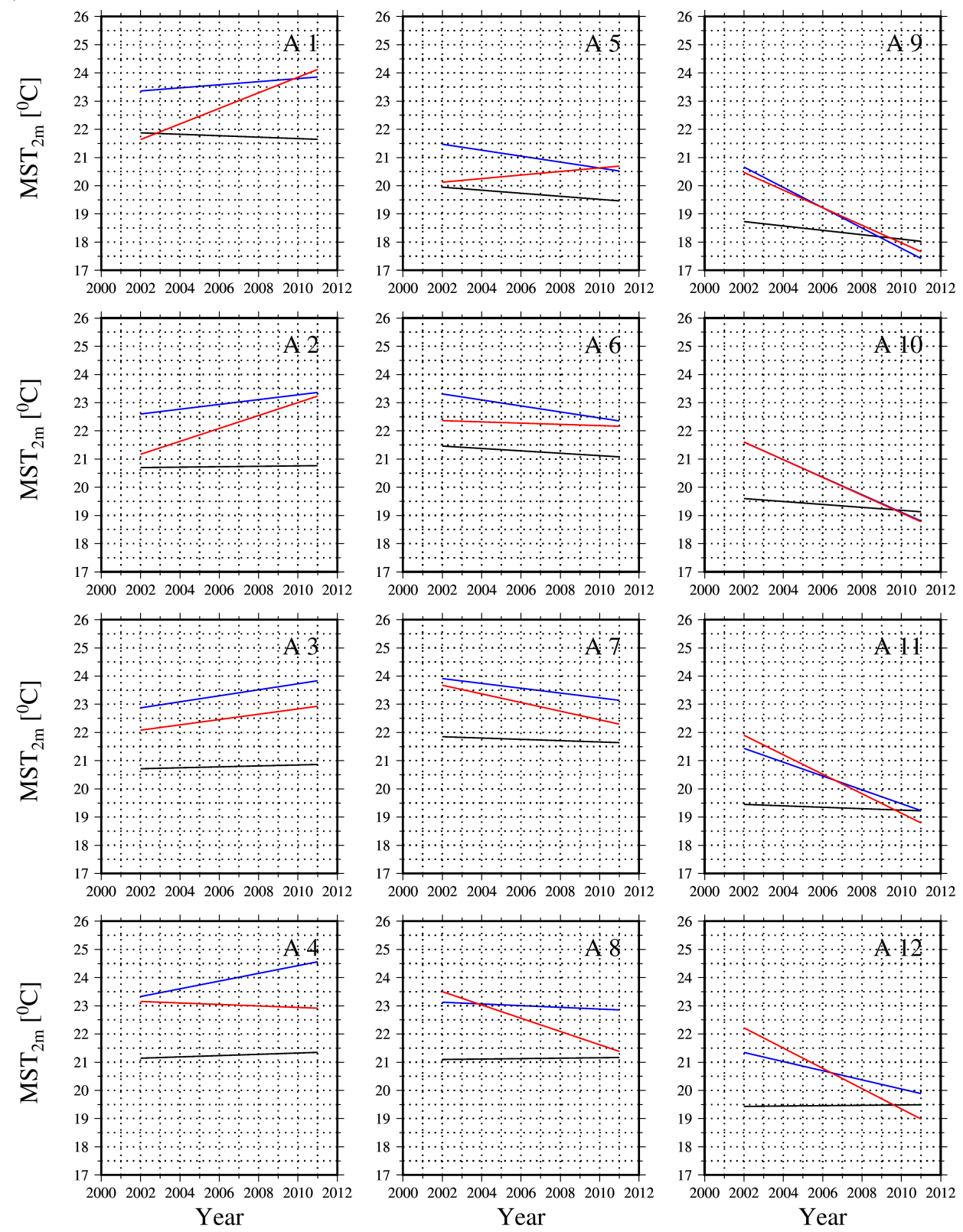

\begin{tabular}{|c|}
\hline Legend \\
$-\mathrm{Y}_{\text {MST2m }}$ with $\mathrm{CF}_{2002}$ for season JJA \\
$-\mathrm{Y}_{\mathrm{MST2m}}$ with $\mathrm{CF}_{0850}$ for season JJA \\
$-\mathrm{Y}_{\mathrm{MST2m}}$ with $\mathrm{CF}_{2050}$ for season JJA \\
\hline
\end{tabular}

Figure 3

Local trends of the mean seasonal air temperatures at surface YMST2m for the summer season, JJA. 

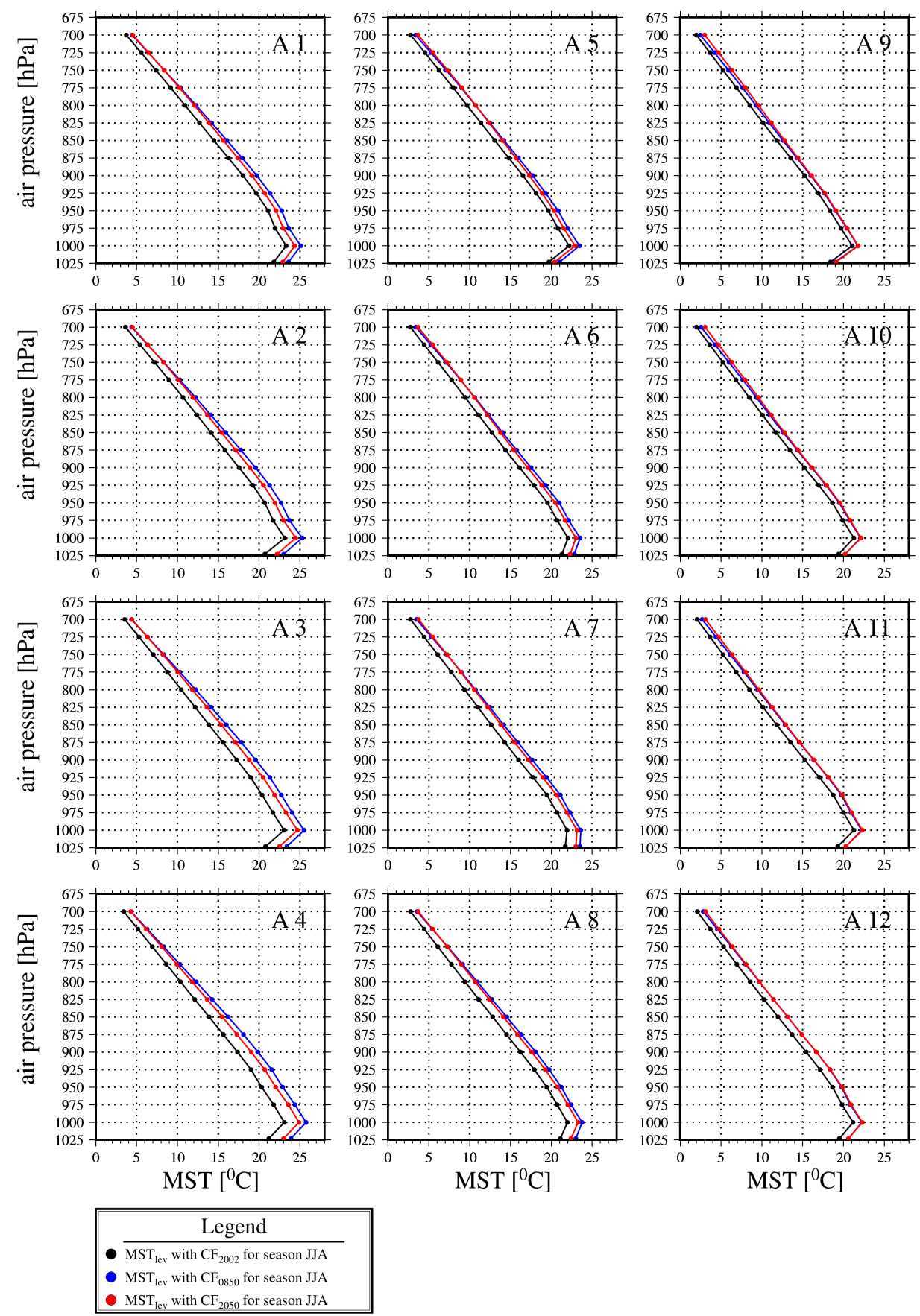

Figure 4

Decadal average of the mean seasonal air temperatures at 13 vertical levels (MSTlev), and at surface (MST2m) for the summer season, JJA. 

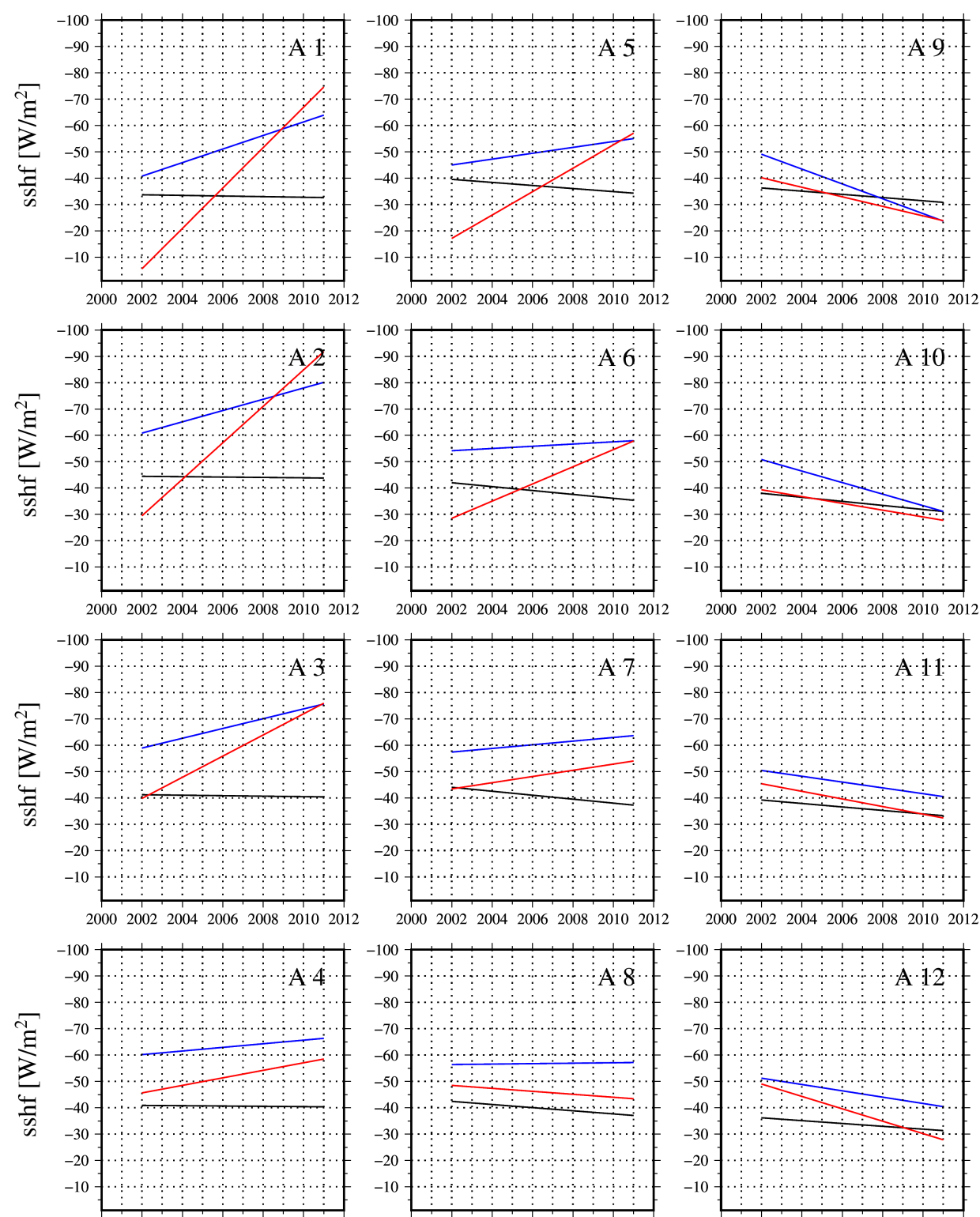

2000200220042006200820102012
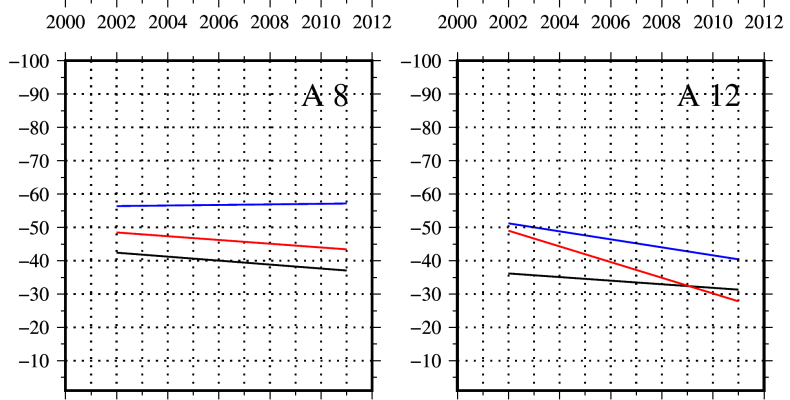

2000200220042006200820102012 Year

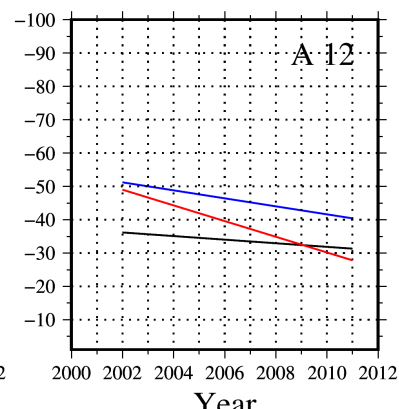

$$
\begin{array}{|c|}
\hline \text { Legend } \\
-\mathrm{Y}_{\text {sshf }} \text { with } \mathrm{CF}_{2002} \text { for season JJA } \\
-\mathrm{Y}_{\text {sshf }} \text { with } \mathrm{CF}_{0850} \text { for season JJA } \\
-\mathrm{Y}_{\text {sshf }} \text { with } \mathrm{CF}_{2050} \text { for season JJA } \\
\hline
\end{array}
$$

Year

Figure 5

Local trends of the surface sensible heat flux at surface Ysshf for the summer season, JJA. 

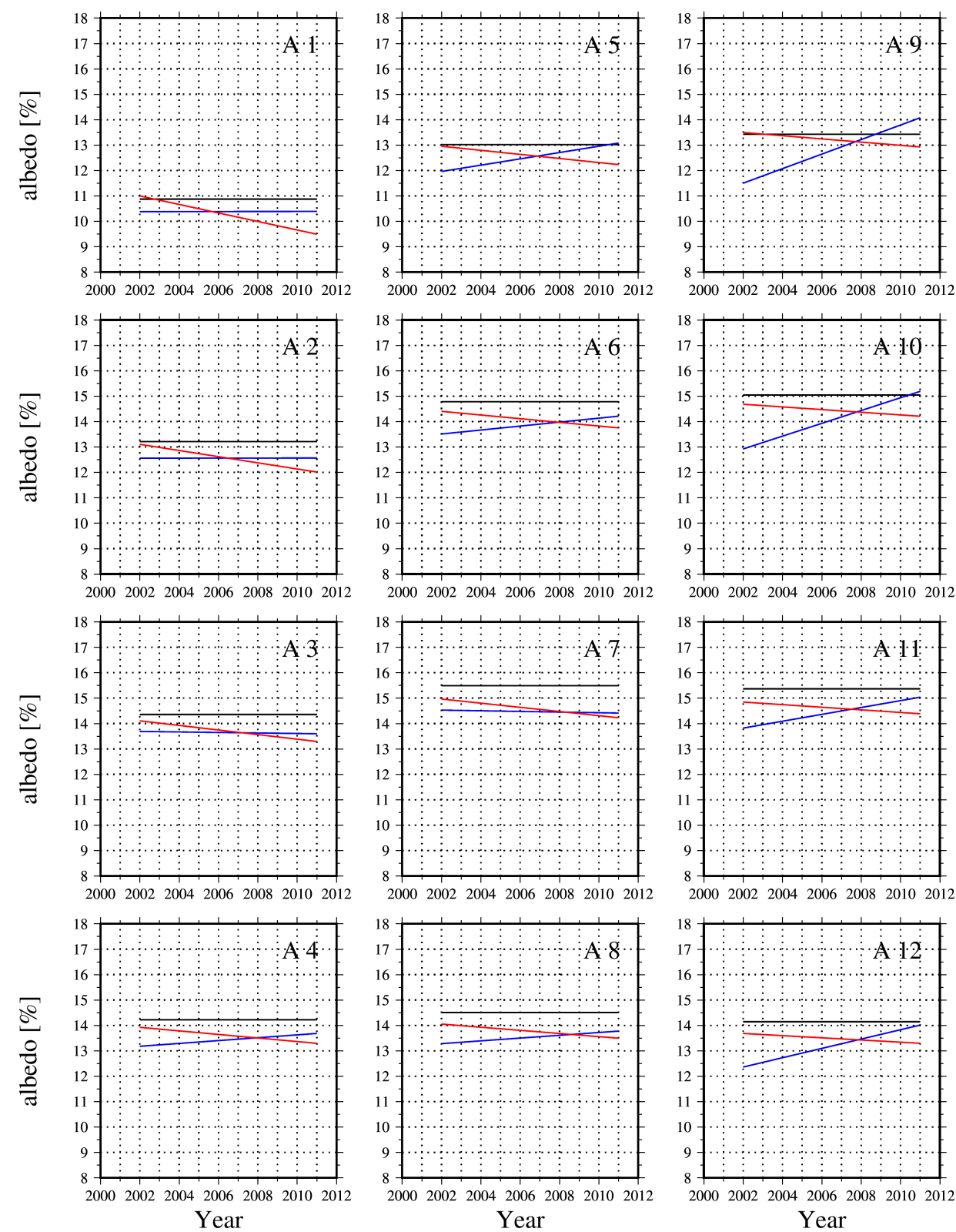

\begin{tabular}{|l|}
\hline \\
$-\mathrm{Y}_{\mathrm{a}}$ with $\mathrm{CF}_{2002}$ for season JJA \\
$-\mathrm{Y}_{\mathrm{a}}$ with $\mathrm{CF}_{0850}$ for season JJA \\
$-\mathrm{Y}_{\mathrm{a}}$ with $\mathrm{CF}_{2050}$ for season JJA \\
\hline
\end{tabular}

Figure 6

Local trends of the surface albedo Yalbedo for the summer season, JJA. 

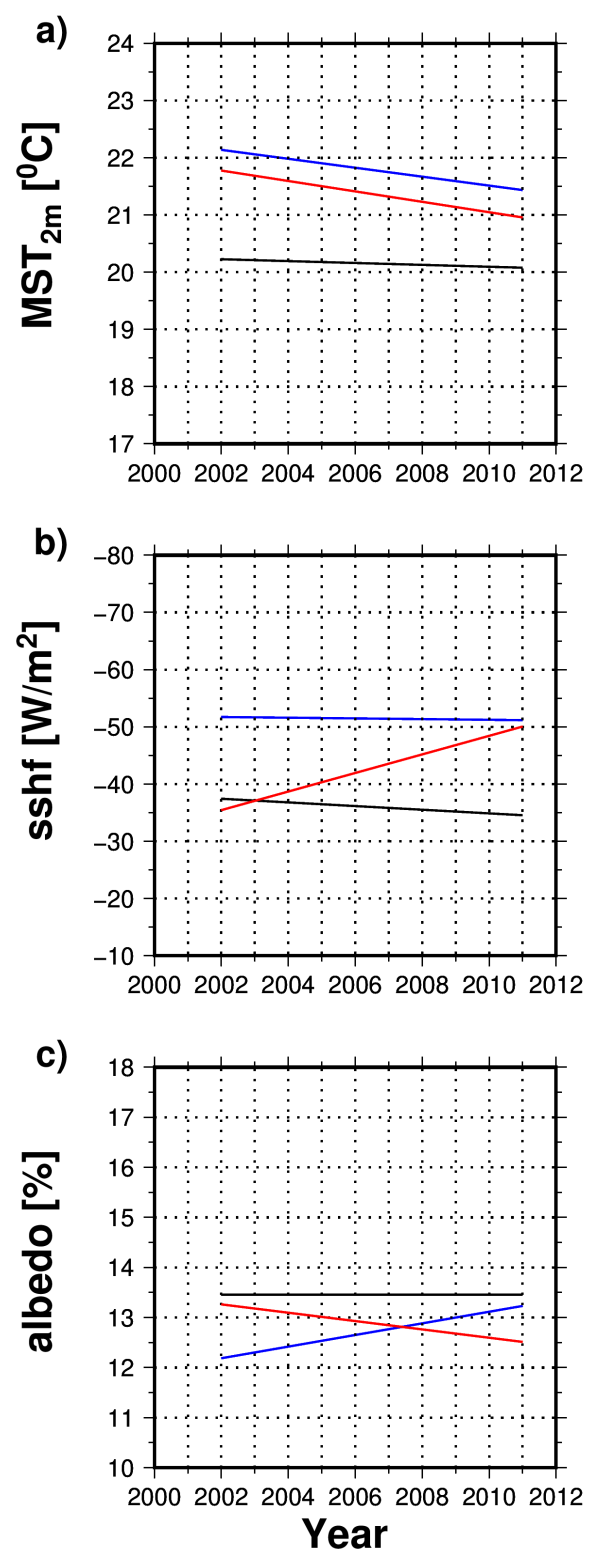

\begin{tabular}{|l|}
\hline Legend \\
- Trend with $\mathrm{CF}_{2002}$ \\
- Trend with $\mathrm{CF}_{0850}$ \\
- Trend with $\mathrm{CF}_{2050}$ \\
\hline
\end{tabular}

\section{Figure 7}

Regional trends for the summer season: a) the air temperatures at the surface YMST2m, b) the surface sensible heat flux at the surface Ysshf, c) the surface albedo Yalbedo. 